Constructing Kanchi 


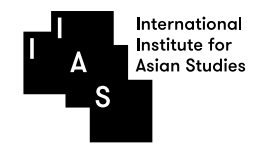

\section{Publications}

The International Institute for Asian Studies (IIAS) is a research and exchange platform based in Leiden, the Netherlands. Its objective is to encourage the interdisciplinary and comparative study of Asia and to promote (inter)national cooperation. IIAS focuses on the humanities and social sciences and on their interaction with other sciences. It stimulates scholarship on Asia and is instrumental in forging research networks among Asia Scholars. Its main research interests are reflected in the three book series published with Amsterdam University Press: Global Asia, Asian Heritages and Asian Cities.

IIAS acts as an international mediator, bringing together various parties in Asia and other parts of the world. The Institute works as a clearinghouse of knowledge and information. This entails activities such as providing information services, the construction and support of international networks and cooperative projects, and the organization of seminars and conferences. In this way, IIAS functions as a window on Europe for non-European scholars and contributes to the cultural rapprochement between Europe and Asia.

IIAS Publications Officer: Paul van der Velde

IIAS Assistant Publications Officer: Mary Lynn van Dijk

\section{Asian Cities}

The Asian Cities Series explores urban cultures, societies and developments from the ancient to the contemporary city, from West Asia and the Near East to East Asia and the Pacific. The series focuses on three avenues of inquiry: evolving and competing ideas of the city across time and space; urban residents and their interactions in the production, shaping and contestation of the city; and urban challenges of the future as they relate to human well-being, the environment, heritage and public life.

\section{Series Editor}

Paul Rabé, Urban Knowledge Network Asia (UKNA) at International Institute for Asian Studies, the Netherlands

\section{Editorial Board}

Henco Bekkering, Delft University of Technology, the Netherlands; Charles Goldblum, University of Paris 8, France; Xiaoxi Hui, Beijing University of Technology, China; Stephen Lau, University of Hong Kong, Hong Kong; Rita Padawangi, Singapore University of Social Sciences, Singapore; R. Parthasarathy, Gujarat Institute of Development Research, Gujarat, India; Neha Sami, Indian Institute of Human Settlements, Bangalore, India 


\title{
Constructing Kanchi
}

City of Infinite Temples

\author{
Emma Natalya Stein
}




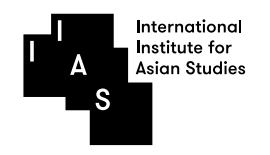

\section{Publications}

\section{Asian Cities 16}

Cover illustration: Festival at Ekāmbaranātha Temple, Kanchi (October 2013) Photograph by Emma Natalya Stein

Cover design: Coördesign, Leiden

Lay-out: Crius Group, Hulshout

$\begin{array}{ll}\text { ISBN } & 9789463729123 \\ \text { e-ISBN } & 9789048550913 \text { (pdf) } \\ \text { DOI } & 10.5117 / 9789463729123 \\ \text { NUR } & 693\end{array}$

(c) Emma Natalya Stein / Amsterdam University Press B.V., Amsterdam 2021

All rights reserved. Without limiting the rights under copyright reserved above, no part of this book may be reproduced, stored in or introduced into a retrieval system, or transmitted, in any form or by any means (electronic, mechanical, photocopying, recording or otherwise) without the written permission of both the copyright owner and the author of the book.

Every effort has been made to obtain permission to use all copyrighted illustrations reproduced in this book. Nonetheless, whosoever believes to have rights to this material is advised to contact the publisher. 
For Bob and all the Babus 
